犊

Global Journals Inc.

(2)

\title{
Seismic Hazard and Total Risk of Existing Large Dams in the Marmara Basin, Turkey
}

By Hasan Tosun

Osmangazi University

Abstract- Safety evaluation is a fundamental stage of existing dams and their appurtenant structures, which have a high-risk potential for downstream life and property. Turkey is a country, which seismically settled at one of the most active regions in the world, and earthquakes with high magnitude frequently occur here. There are some regions, which are severely under threatening of earthquakes. One of them is the Marmara region with twenty-four million people. This region, namely the Marmara basin, has at least forty-five large dams with different types. This study considered nineteen of them to relieve their seismic hazard parameters for all dam sites and total risk for each structure. The study area is lying in a seismically, very active part of Turkey. The southern part of the basin is structurally cut by the North Anatolian Fault, which is a famous structural feature that produces deathful earthquakes, and its offshoots. The analyses have indicated that peak acceleration widely ranges for the nineteen dam sites of this basin. The total risk analyses have concluded that most of the dams in the metropolitan area have high-risk classes and a significant effect for public safety.

Keywords: dam, earthquake, seismic hazard, total risk.

GJRE-E Classification: FOR Code: 090599

Strictly as per the compliance and regulations of:

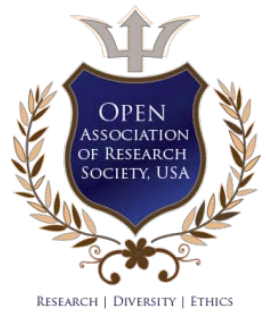

(C) 2020. Hasan Tosun. This is a research/review paper, distributed under the terms of the Creative Commons AttributionNoncommercial 3.0 Unported License http://creativecommons.org/licenses/by-nc/3.0/), permitting all non-commercial use, distribution, and reproduction in any medium, provided the original work is properly cited. 


\title{
Seismic Hazard and Total Risk of Existing Large Dams in the Marmara Basin, Turkey
}

\author{
Hasan Tosun
}

\begin{abstract}
Safety evaluation is a fundamental stage of existing dams and their appurtenant structures, which have a high-risk potential for downstream life and property. Turkey is a country, which seismically settled at one of the most active regions in the world, and earthquakes with high magnitude frequently occur here. There are some regions, which are severely under threatening of earthquakes. One of them is the Marmara region with twenty-four million people. This region, namely the Marmara basin, has at least forty-five large dams with different types. This study considered nineteen of them to relieve their seismic hazard parameters for all dam sites and total risk for each structure. The study area is lying in a seismically, very active part of Turkey. The southern part of the basin is structurally cut by the North Anatolian Fault, which is a famous structural feature that produces deathful earthquakes, and its offshoots. The analyses have indicated that peak acceleration widely ranges for the nineteen dam sites of this basin. The total risk analyses have concluded that most of the dams in the metropolitan area have high-risk classes and a significant effect for public safety.
\end{abstract}

Keywords: dam, earthquake, seismic hazard, total risk.

\section{InTRODUCTION}

T he ratings of seismic hazard of the dam site and the risk potential of the structure are the main factors acting on public safety for downstream life. The peak ground acceleration, derived from the design earthquake that produces the seismic loads, is a mainly used criteria of the seismic hazard of a dam site. The dam height, reservoir capacity, potential downstream damages and evacuation requirements are the parameters for assessing risk rating of the dam. Tosun (2012) states that risk evaluation utilized the structure characteristics and seismic hazard ratings separately. According to Bureau (2003), the total risk factor for dam structure should depend on together these two factors. Recently, the ICOLD (2016) has published the guideline for selecting seismic parameters for large dams.

Turkey is a country that desires to use land and water resources effectively. The total number of large dams constructed throughout the country is more than 1250. Most of them are of the embankment type. However, the number of concrete and rolled-compacted concrete dams increase recently. The dam design engineers in Turkey think that embankment dams are a suitable type for the sites having high seismic activity, when well compacted according to the specifications. However, the author states that strong ground shaking can result in instability of embankments of the earth and rockfills and loss of strength at the foundations, especially for dams that are under near-source effect. Author and co-workers have so many research studies for the structures discussed in the basin and neighboring areas (Tosun and Tosun, 2017a; Tosun, 2018; Tosun and Onder, 2018; Tosun et al. 2020). They also studied on river basin risk analysis and seismic hazard of large dams in Turkey (Tosun and Seyrek, 2010; Tosun, 2011; Seyrek and Tosun, 2011; Tosun, 2012; Seyrek and Tosun, 2013; Tosun, 2015; Tosun and Oguz, 2017; Tosun and Tosun, 2017b).

The study considers existing large dams in the Marmara basin, which covers lands around the Marmara Sea in Turkey (Fig.1). This basin has a surface area of 2.31 million ha with a water yield resources of 8.3 billion cu.m per year at the Northwest Anatolia. This study deals with an assessment of seismic hazard and total risk, and evaluates 19 large dams, which have a hydraulic height between 10.1 and $109.0 \mathrm{~m}$, in the Marmara basin. Table 1 shows their technical characteristics. There are twelve large dams in the basin for providing domestic water to the Istanbul Metropolitan area in which seventeen million people are living. However, the existing dams in the Northern part of the basin, which were constructed by the Istanbul Water and Sewerage Administration, were excluded in this study because of being lack of data. 
Table 1: Technical characteristics of dams considered for this study (DSI, 2016)

\begin{tabular}{|c|c|c|c|c|c|c|c|}
\hline$\#$ & Dam & $\operatorname{Aim}\left({ }^{\star}\right)$ & $\begin{array}{l}\text { Height from } \\
\text { river bed } \\
\text { (m) }\end{array}$ & $\begin{array}{l}\text { Completed } \\
\text { Year }\end{array}$ & Type $\left({ }^{* \star}\right)$ & $\begin{array}{l}\text { Volume of } \\
\text { embankment } \\
\left(\mathrm{hm}^{3}\right)\end{array}$ & $\begin{array}{c}\text { Volume of } \\
\text { reservoir } \\
\left(\mathrm{hm}^{3}\right)\end{array}$ \\
\hline 1 & Alibey & $D+F$ & 28.0 & 1983 & $\mathrm{EF}$ & 1.927 & 65.00 \\
\hline 2 & Armagan & 1 & 57.5 & 1999 & $\mathrm{RF}$ & 1.560 & 51.50 \\
\hline 3 & Atikhisar & $I+D+F$ & 33.7 & 1973 & $\mathrm{EF}$ & 2.218 & 52.20 \\
\hline 4 & Bakacak & 1 & 50.0 & 1998 & RF & 2.200 & 139.00 \\
\hline 5 & Bayramdere & $1+D$ & 56.0 & 2011 & RF & 1.000 & 18.45 \\
\hline 6 & Buyukçekmece & $\mathrm{D}$ & 10.1 & 1987 & $\mathrm{EF}$ & 1.718 & 172.45 \\
\hline 7 & Cokal & $1+D$ & 57.0 & 2011 & CFR & 3.500 & 204.00 \\
\hline 8 & Darlık & D & 73.0 & 1988 & RF & 1.600 & 107.00 \\
\hline 9 & Elmali II & $\mathrm{D}$ & 42.5 & 1955 & CG & 0.103 & 10.31 \\
\hline 10 & Gokce & $\mathrm{D}$ & 50.0 & 1989 & $\mathrm{EF}+\mathrm{RF}$ & 0.133 & 21.71 \\
\hline 11 & Gokceada & $1+D$ & 33.0 & 1983 & $\mathrm{EF}$ & 0.560 & 16.80 \\
\hline 12 & Kadikoy & $I+D+F$ & 34.1 & 1973 & $\mathrm{EF}$ & 0.680 & 56.50 \\
\hline 13 & Kirazlıdere & $\mathrm{D}$ & 109.0 & 1999 & RF & 5.200 & 60.00 \\
\hline 14 & Omerli & $\mathrm{D}$ & 52.0 & 1972 & $\mathrm{EF}$ & 1.650 & 436.53 \\
\hline 15 & Sazlidere & $\mathrm{D}$ & 23.0 & 1996 & RF & 1.780 & 131.50 \\
\hline 16 & Tasoluk & 1 & 65.0 & 2009 & RF & 1.700 & 79.40 \\
\hline 17 & Tayfur & $\mathrm{D}$ & 39.0 & 1985 & $\mathrm{RF}$ & 0.298 & 4.36 \\
\hline 18 & Umurbey & 1 & 81.0 & 2003 & $\mathrm{EF}$ & 2.400 & 24.56 \\
\hline 19 & YeniceGonen & $\mathrm{I}+\mathrm{D}+\mathrm{E}+\mathrm{F}$ & 70.0 & 1997 & $\mathrm{RF}+\mathrm{EF}$ & 2.400 & 227.04 \\
\hline
\end{tabular}

$\left.{ }^{*}\right)$ D: Domestic Water, E: Energy, F: Flood control, I: Irrigation and IU: Industrial use

$\left.{ }^{(*}\right)$ CFR: Concrete faced rock, EF:Earthfill, RF:Rockfill and CG:Concrete Gravity

\section{Methods of Analysis}

Seismic hazard is the main factor acting on the total risk of dam structures. The peak ground acceleration (PGA) is the parameter to be used in defining the seismic hazard of a dam site. For each dam site, author identifies all possible seismic sources and evaluates their potential in detail, as based on the guidelines (Fraser, 2002) and the unified seismic hazard modeling for the Mediterranean region introduced by Jiminez et al (2001). The extensive surveys and a search of available literature identify several energy sources to analyze the seismic hazard of dams in Turkey. The seismic hazard analyses also depend on the data instrumentally recorded earthquakes that occurred within the last 100 years. As summary, the study considers seismic zones and earthquakes within the area having a radius of $100 \mathrm{~km}$ around the dam site.

The seismic hazard study includes probabilistic and deterministic analyses. For dam sites, design engineers generally use the deterministic and probabilistic seismic hazard analyses. The deterministic seismic hazard analysis (DSHA) considers a scenario having a four-step process and provides a straightforward framework for the assessment of the worst ground motions. The probabilistic seismic hazard analysis (PSHA) defines a framework for uncertainties to identify and combine in a rational manner. DSHA takes into account geology and seismic history to identify earthquake sources and to interpret the strongest earthquake with regardless of time. In comparison, the PSHA considers uncertainties in size, location and recurrence rate of earthquakes (Kramer, 1996; Krinitzsky, 2005).

The study adopted various attenuation relationships to calculate the peak ground acceleration (PGA) acting on dam sites due to unavailability of strong motion records. This study primarily taken into account eight separate predictive relationships for horizontal peak ground acceleration (Campbell, 1981; Boore et al.1993; Ambraseys, 1995; Campbell \& Bozorgnia, 1994; Boore et al. 1997; Gulkan \& Kalkan, 2002; Kalkan \& Gülkan, 2004; Ambraseys et al. 2005). However, the author excluded some data for the study because of giving extreme values. 
International Commission on Large Dams (ICOLD) defined new terms, namely the Maximum Credible Earthquake (MCE) and the Safety Evaluation Earthquake (SEE), in its recently published documents (ICOLD, 2016). However, this study considers earthquake definitions given by Federal Emergency Management Agency (FEMA).This organization defines the Operating Basis Earthquake (OBE), the Maximum Design Earthquake (MDE) and the Safety Evaluation Earthquake (SEE) for different level of shaking (FEMA, 2005).In Turkey, there are so many examples analyzed by using these definitions in the past. (Tosun and Savas, 2005; Tosun, 2006; Tosun, 2007; Tosun and Turkoz, 2007; Tosun et al. 2007a, 2007b and 2007c; Tosun, 2008; Tosun and Seyrek, 2012; Tosun, 2015; Tosun \& Tosun, 2017b). Recently, they pointed out that risk assessment is an important aspect for dams and their appurtenant structures (Tosun, 2019a; Hariri-Ardebeli et al. 2020) .

\section{ili. Seismic HaZArd Analyses}

The analyses of seismic hazard in this context consider all possible seismic sources for dam sites in the Marmara basin based on the zonation map of Turkey, prepared by The National Disaster Organization and other Institutes for general use. The author and his co-workers modified it to use for dam projects. They considered seismic history and local geological features to quantify the rate of seismic activity in the basin. The detailed evaluation indicated that there are twoseparated seismic zones in the related area.

In Turkey, The National Geological Survey released a new seismo-tectonic map to the public in 2013 (MTA, 2013). Fig.1also shows the study area on the national seismo-tectonics model. The ICOLD (2016) defined the near-field motion, which is ground motion recorded in the vicinity of a fault. This specification suggested a correlation between the radius of near field area and earthquake magnitude based on the cases in West United States. The author established limits of near-field motion for the investigation area. According to this model, there are eight dams, which are under the near-field motion. The model indicated that earthquakes having a magnitude ( $\mathrm{Mw}$ ) between 5.6 and 7.5 can be possible and the minimal distance to the fault segment can range between 1.7 and $121.1 \mathrm{~km}$ in the basin. Five existing dams considered in this study are under nearfield motion (Table 2).

The deterministic analyses indicate that peak ground acceleration (PGA) changes within an acceptable range when excluded five dams, which are under the near-field motion. The PGA values range from $0.036 \mathrm{~g}$ to $0.394 \mathrm{~g}$ for the 50 th percentile and from $0.061 \mathrm{~g}$ to $0.650 \mathrm{~g}$ for the 84th percentile, respectively (Table 2). The PGA data are very high for the Yenice-Gonen, Tasoluk, Kirazdere, Gokce and Cokal dams. For Alibey,
Buyuk-Cekmece and Sazlıdere dams, the PGA values are also at a considerable level even if they are not under near-field motion.

The probabilistic hazard analyses introduce PGA values within a wide range. For MDE, those are between $0.120 \mathrm{~g}$ and $0.630 \mathrm{~g}$, while the same values range from $0.102 \mathrm{~g}$ to $0.509 \mathrm{~g}$ for $\mathrm{OBE}$. The PGA data for OBE and MDE are high for the dams, which are under near-field motion, mentioned above for deterministic analyses. It is an impressive result that maximum PGA values for OBE, MDE, and SEE belong to the Gokce dam even if its energy source produces a moderate magnitude earthquake (5.9 in Mw). The author thinks that it probably depends on earthquake intensity. The probabilistic hazard analyses also give critical values for Cokal, Kirazdere, Tasoluk, and Yenice dams as given in deterministic hazard analyses. 


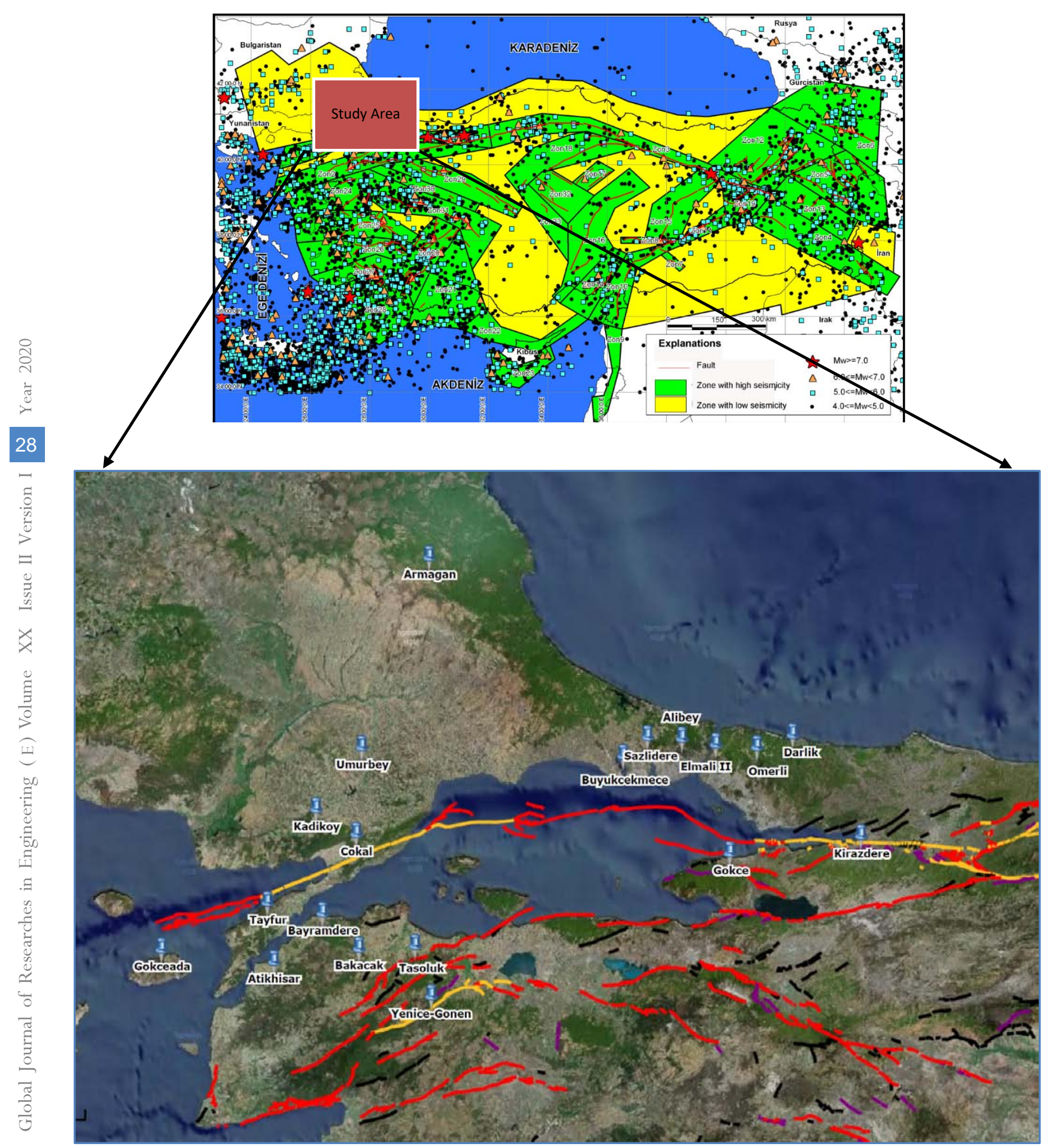

Figure 1: Location of dams on the national seismo-tectonics model and the active fault map (Active faults-yellow color: earthquake surface fracture, red color: Holocene fault, purple color: Quaternary fault, black color: possible Quaternary fault) 
Table 2: Results of seismic hazard analyses

\begin{tabular}{|c|c|c|c|c|c|c|c|c|}
\hline \multirow{2}{*}{$\#$} & \multirow{2}{*}{ Dam } & \multicolumn{4}{|c|}{ Deterministic Method * } & \multicolumn{3}{c|}{ Probabilistic Method ** } \\
\cline { 3 - 9 } & $\mathrm{M}_{\max }$ & $\mathrm{R}_{\min }(\mathrm{km})$ & $\begin{array}{c}\text { Mean PGA } \\
+50 \\
(\%)\end{array}$ & $\begin{array}{c}\text { Mean PGA } \\
+84 \\
(\%)\end{array}$ & $\begin{array}{c}\text { OBE } \\
\text { in g }\end{array}$ & MDE in g & $\begin{array}{c}\text { SEE } \\
\text { in g }\end{array}$ \\
\hline 1 & Alibey & 7.5 & 25.1 & 0.191 & 0.313 & 0.229 & 0.298 & 0.413 \\
\hline 2 & Armagan & 6.5 & 121.1 & 0.036 & 0.061 & 0.102 & 0.120 & 0.147 \\
\hline 3 & Atikhisar & 6.5 & 40.1 & 0.098 & 0.163 & 0.200 & 0.243 & 0.300 \\
\hline 4 & Bakacak & 6.6 & 18.2 & 0.153 & 0.255 & 0.302 & 0.380 & 0.492 \\
\hline 5 & Bayramdere & 6.2 & 26.4 & 0.091 & 0.152 & 0.239 & 0.293 & 0.365 \\
\hline 6 & Buyukçekmece & 7.5 & 14.8 & 0.281 & 0.468 & 0.286 & 0.393 & 0.558 \\
\hline 7 & Cokal & 6.3 & 2.7 & 0.327 & 0.540 & 0.509 & 0.639 & 0.825 \\
\hline 8 & Darlik & 7.7 & 41.2 & 0.141 & 0.230 & 0.146 & 0.195 & 0.268 \\
\hline 9 & Elmali II & 7.5 & 27.3 & 0.178 & 0.292 & 0.210 & 0.285 & 0.394 \\
\hline 10 & Gokce & 5.9 & 3.1 & 0.285 & 0.469 & 0.583 & 0.709 & 0.887 \\
\hline 11 & Gokceada & 6.3 & 21.9 & 0.101 & 0.167 & 0.264 & 0.324 & 0.410 \\
\hline 12 & Kadikoy & 6.3 & 22.5 & 0.120 & 0.198 & 0.276 & 0.344 & 0.441 \\
\hline 13 & Kirazlidere & 6.7 & 5.3 & 0.329 & 0.544 & 0.433 & 0.560 & 0.747 \\
\hline 14 & Omerli & 7.7 & 34.6 & 0.164 & 0.267 & 0.178 & 0.238 & 0.329 \\
\hline 15 & Sazlidere & 7.5 & 23.0 & 0.205 & 0.335 & 0.225 & 0.306 & 0.428 \\
\hline 16 & Tasoluk & 5.6 & 1.8 & 0.261 & 0.429 & 0.460 & 0.582 & 0.761 \\
\hline 17 & Tayfur & 6.3 & 18.4 & 0.130 & 0.216 & 0.370 & 0.451 & 0.565 \\
\hline 18 & Umurbey & 6.7 & 42.2 & 0.083 & 0.138 & 0.193 & 0.238 & 0.299 \\
\hline 19 & YeniceGonen & 6.6 & 1.77 & 0.394 & 0.650 & 0.391 & 0.513 & 0.702 \\
\hline
\end{tabular}

\section{Total Risk Analyses}

Throughout this study, the total risk analyses of the basin considered the national specification (DSI, 2012). in which total risk factor depends on reservoir capacity, height, evacuation requirement, and potential hazard, and the Bureau method, which considers dam characteristics, evacuation requirements and downstream damage potential. The national specification adopted the ICOLD (1989) guidelines. The Bureau method recommends four separate risk classes ranging from I (low risk) to IV (extreme risk) as based on the Total Risk Factor (TRF).

Table 3 summaries the total risk analyses of the dams considered in the study. Five dams (Cokal, Gokce, Kirazdere, Tasoluk, and Yenice-Gonen) classified into extremely high hazard ratios with class IV.In comparison, four dams (Alibey, Buyuk-Cekmece, Elmali-II and Sazlidere) have high hazard rating with hazard class of III. Others are identified in classes of I and II (low to moderate hazard rating). The ICOLD (1989) specification classified dams into hazard class IV with hazard rating of extreme, if the PGA value is greater than $0.25 \mathrm{~g}$ and the energy source is closer than $10 \mathrm{~km}$ from the dam site. According to this statement, five dams mentioned above are classified as hazard class IV with a hazard rating of extreme. Throughout study, most dams, classified into hazard classes of III and IV, have a function to provide domestic water for the metropolitan areas.

For nine dams classified into hazard classes of III and IV, the distance from the dam site to active faults, given on updated seismic maps, ranges from $1.7 \mathrm{~km}$ to $27.3 \mathrm{~km}$. The large dams of basins, which are under the influence of the near-field motion, have been constructed to very close to the North Anatolian Fault Zone or its offsets passing through from south of the investigation area.

According to DSI Guidelines, all dams with the exception of one structure (Tayfur dam) are categorized into III and IV risk classes with a high and very extremely high-risk rating. Following the Bureau's method, five large dams are classified in risk class III, high-risk rating, while others are in the moderate risk ratio with class of II. The total risk analyses indicate that the solutions obtained from the Bureau method are more rational than those estimated by the DSI guidelines. 
Table 3: The total risk of dams considered for this study

\begin{tabular}{|c|c|c|c|c|c|c|c|c|c|}
\hline \multirow{2}{*}{$\#$} & \multirow{2}{*}{ Dam } & \multicolumn{2}{|c|}{ Hazard Analysis } & \multicolumn{2}{c|}{ Total Risk (ICOLD,1989) } & \multicolumn{3}{c|}{ Total Risk (Bureau, 2003) } \\
\cline { 2 - 10 } & Class & $\begin{array}{c}\text { Hazard } \\
\text { Ratio }\end{array}$ & $\begin{array}{c}\text { Risk } \\
\text { factor }\end{array}$ & $\begin{array}{c}\text { Risk } \\
\text { class }\end{array}$ & Risk ratio & $\begin{array}{c}\text { Risk } \\
\text { factor }\end{array}$ & $\begin{array}{c}\text { Risk } \\
\text { class }\end{array}$ & Risk ratio \\
\hline 1 & Alibey & III & High & 30 & III & High & 223.30 & III & High \\
\hline 2 & Armagan & I & Low & 30 & III & High & 99.28 & II & Moderate \\
\hline 3 & Atikhisar & I & Low & 24 & III & High & 143.97 & III & High \\
\hline 4 & Bakacak & II & Moderate & 36 & IV & Very high & 137.55 & III & High \\
\hline 5 & Bayramdere & I & Low & 26 & III & High & 83.98 & II & Moderate \\
\hline 6 & Buyukçekmece & III & High & 22 & III & High & 150.80 & III & High \\
\hline 7 & Cokal & IV & Extreme & 36 & IV & Very high & 141.14 & III & High \\
\hline 8 & Darllk & II & Moderate & 32 & IV & Very high & 160.30 & III & High \\
\hline 9 & Elmali II & III & High & 32 & IV & Very high & 180.20 & III & High \\
\hline 10 & Gokce & IV & Extreme & 34 & IV & Very high & 124.55 & II & Moderate \\
\hline 11 & Gokceada & II & Moderate & 24 & III & High & 136.27 & III & High \\
\hline 12 & Kadikoy & II & Moderate & 24 & III & High & 143.35 & III & High \\
\hline 13 & Kirazdere & IV & Extreme & 34 & IV & Very high & 146.09 & III & High \\
\hline 14 & Omerli & II & Moderate & 36 & IV & Very high & 217.0 & III & High \\
\hline 15 & Sazlidere & III & High & 32 & IV & Very high & 158.40 & III & High \\
\hline 16 & Tasoluk & IV & Extreme & 34 & IV & Very high & 116.85 & II & Moderate \\
\hline 17 & Tayfur & II & Moderate & 16 & II & Moderate & 67.10 & II & Moderate \\
\hline 18 & Umurbey & I & Low & 26 & III & High & 134.82 & III & High \\
\hline 19 & YeniceGonen & IV & Extreme & 36 & IV & Very high & 214.06 & III & High \\
\hline
\end{tabular}

The TRF values range from 67.10 to 223.3 according to the Bureau method. There are five dams of a risk class of II and fourteen dams of a risk class of III, while there is no dam having a risk class of I in the basin. In other words, seventy-four percent of total dams are identified as a risk class of III with high risk ratio, while the rest are being in class of II with moderate risk ratio.

\section{Discussions}

There are so many small and large dams in the Marmara basin, Turkey. Some of them, namely Alibey, Buyuk-Cekmece, Cokal, Elmali-II, Gokce, Kirazdere, Sazlidere, Tasoluk, and Yenice-Gonen, has mainly been built for providing domestic water and located in the metropolitan area. These dams have been discussed in more detail in the papers submitted in the local symposiums held in Turkey (Tosun and Onder, 2018 and Tosun, 2019b). The dams, categorized into hazard class of III and IV with high to extremely high hazard ratio and into the total risk of III with high-risk ratio, can cause very serious conditions for downstream life and property when they fail. The author evaluates their earthquake safety and total risk in more detail as given below.

Alibey Dam, located on Alibey river in the Marmara basin, is an embankment dam 28.0-m high with a total embankment volume of $1927000 \mathrm{m3}$. The facility will impound $65.0 \mathrm{hm} 3$ of water with a reservoir surface area of $4.75 \mathrm{~km} 2$ at the maximum water level. It provides domestic water with an annual capacity of 33.0 $\mathrm{hm} 3$. The side slopes of the main embankment are 2.0H:1V for both upstream and downstream $(\mathrm{H}=$ horizontal and $\mathrm{V}=$ vertical $))$. In the section, there are a central impervious zone, which is composed of impervious clay, and a transition section of granular materials to protect the central impervious clay. The shell fill in downstream and upstream parts is composed of semi-pervious clayey material. The geotechnical engineers designed vertical sand drains to provide quick-consolidation of the clayey layer of soft alluvium on the river bed. The analyses indicate that this dam is one of the more critical structure within the Istanbul Metropolitan Area. According to DSHA, the peak ground acceleration resulted by an earthquake of 7.5 magnitudes is $0.191 \mathrm{~g}$. As based on PSHA, the values of peak ground acceleration for OBE and MDE are $0.229 \mathrm{~g}$ and $0.298 \mathrm{~g}$, respectively. It is $25.1 \mathrm{~km}$ far away from an active fault given in the new seismo-tectonic map of Turkey adopted in 2013. The dam, identified a risk class of III, hasa TRF value of 223.3. The 37-years old embankment is in excellent condition. However, the author recommends its seismic upgrade soon.

Buyuk-Cekmece dam is an earthfill dam located in the Istanbul Metropolitan Area. It has only a $10.1 \mathrm{~m}$ height from the river bed, however, its total storage capacity is relatively high. When the reservoir is at maximum capacity, the facility impounds $172.5 \mathrm{hm} 3$ of 
water with a reservoir surface area of $28.58 \mathrm{~km} 2$. It provides domestic water with an annual capacity of 82 hm3 for the European part of the Istanbul metropolitan area. The crest length is $2476 \mathrm{~m}$, and the side slopes of main embankment are3.0H:1V for both upstream and downstream side $(\mathrm{H}=$ horizontal and $\mathrm{V}=$ vertical). In the section, there are a central impervious core, which is composed of compacted impervious clay, and a transition section of sandy and gravelly aggregates between the core clay and semi-pervious soils. The alluvium on the river bed, which is composed of different sizes of river bed material, was removed before beginning the construction of the main embankment of dam. According to the DSHA, the peak ground acceleration by an earthquake of 7.5 magnitudes is $0.281 \mathrm{~g}$. The PSHA indicates that the values of peak ground acceleration for OBE and MDE are $0.286 \mathrm{~g}$ and $0.393 \mathrm{~g}$, respectively. The dam embankment is only 14.8 $\mathrm{km}$ far away from an active fault given in the new seismo-tectonic map of Turkey adopted for 2013.The dam, identified as a risk class of III, has a TRF value of150.8. This 31-year old earthfill dam is in excellent condition, but it cannot meet current seismic design standards. Additionally, it is relatively close to the energy source.

Cokal dam, located at the European part of the Marmara basin, was designed as the type of concrete faced rockfill dam (CFRD). It impounds $204.0 \mathrm{hm} 3$ of water at maximum water level and has $81 \mathrm{~m}$ height from the foundation and $571 \mathrm{~m}$ length on the crest. The dam body is mainly composed of rockfill material. There is a transition section between the face concrete lining and rockfill. The side slopes are $1.4 \mathrm{H}$ : $1 \mathrm{~V}$ for upstream and downstream of dam body (Fig.2). The impervious section consists of the concrete slab and the plinth structure on the downstream face. The alluvium on the river bed, which is composed of sandy and gravelly clay, was removed before commencing the construction of the dam body. According to the DSHA, the peak ground acceleration resulted by an earthquake of 6.3 magnitudes is $0.327 \mathrm{~g}$ as based on PSHA, the values of peak ground acceleration for OBE and MDE are $0.509 \mathrm{~g}$ and $0.639 \mathrm{~g}$, respectively. The dam is only $2.7 \mathrm{~km}$ far away from the main faulting system, which has a surface rupture of the North-Anatolian Faulting System in the west. The dam, identified as a risk class of III, has a TRF value of 141.1. Intensive investigations showed that the behavior of CFRD's is questionable after the Wenchuan earthquake of 12 May 2008 in China (Tosun, 2015). Cokal dam is one of most critical structures of the Marmara basin. Therefore, it should be re-analyzed using sophisticated programs to describe its dynamic behavior under severe excitation conditions even if it is a young dam.

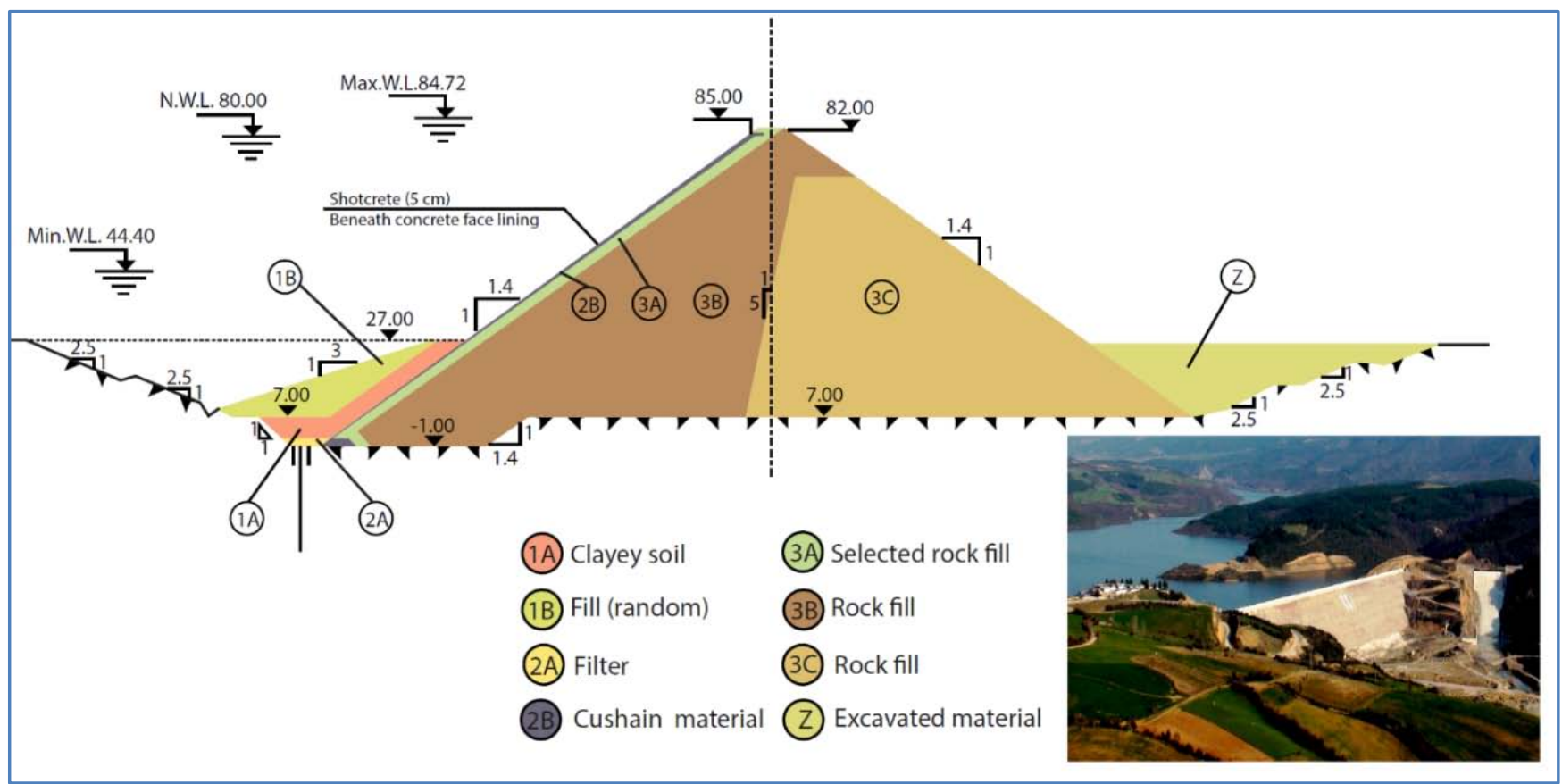

Figure 2: Maximum cross-section of Cokal dam

The Elmali-Il dam is a unique rigid-typed structure of the basin with a volume of $0.10 \mathrm{hm} 3$ of concrete gravity body. The dam, located on the Goksu river in the Anatolian part of Istanbul Metropolitan Area, has 65-years old. Its height from river bed is $42.5 \mathrm{~m}$. At the maximum water level, the facility will impound 10.31 hm3 of water with a reservoir surface area of $42 \mathrm{~km} 2$. Its function is to provide domestic water for Istanbul city. The seismic hazard analyses indicate that this dam is one of safe structures within the Marmara basin. The peak ground acceleration produced by an earthquake of 7.5 magnitudes is $0.178 \mathrm{~g}$, and it is $27.3 \mathrm{~km}$ far away

\section{.}


from an active fault. The PSHA indicates that the values of peak ground acceleration for OBE and MDE are $0.210 \mathrm{~g}$ and $0.285 \mathrm{~g}$, respectively. Its TRF value is 180.2 , and it has a risk class of III. The Elmali-II dam, which is the oldest one of the dams considered for this study is in excellent condition. However, it is necessary to have a seismic upgrade for the dam soon.

Gokce dam is an earth-rockfill typed with a total embankment volume of $133000 \mathrm{~m} 3$.The 50-m high dam, located on the Gokce river in Marmara basin, has a function for providing domestic water of Yalova city and its vicinity. The facility approximately will impound $21.71 \mathrm{hm} 3$ of water with a reservoir surface area of 1.3 $\mathrm{km} 2$ at the maximum water level. The crest width is 10 $\mathrm{m}$, and the side slopes of main embankment are 3.0H:1V for upstream and 2.0H: $1 \mathrm{~V}$ for downstream ( $H=$ horizontal and $\mathrm{V}=$ vertical). In the section, there are a central impervious core, which is composed of compacted clay, and a transition section of sand, gravel and small-sized crushed rock between the core and rockfill materials for the downstream part and a natural filter zone between the core and earthfill material for the upstream. The downstream shells consist of large-sized crushed rocks. The DSHA and PSHA indicate that Gokcedam is one of the most critical dams within the basin. The DSHA indicates that the peak ground acceleration produced an earthquake of 5.9 magnitudes is $0.285 \mathrm{~g}$, and its embankment is $3.1 \mathrm{~km}$ far away from a secondary active fault given in the updated seismotectonic map of Turkey. According to PSHA, the values of peak ground acceleration for OBE and MDE are $0.583 \mathrm{~g}$ and $0.709 \mathrm{~g}$, respectively. Its TRF value is 124.6 , and the 31-years old dam has a risk class of III with high risk ratio.

Kirazdere dam is a rockfill dam on the Kirazdere River within the Kocaeli Metropolitan area. It has a 109.0 $\mathrm{m}$ height from river bed. When the reservoir is at maximum capacity, the facility impounds $60.0 \mathrm{hm} 3$ of water in its reservoir. The dam, finished in 1999, has a function to provide domestic water with an annual capacity of $142 \mathrm{hm} 3$. According to the deterministic seismic hazard analyses, the peak ground acceleration produced by an earthquake of 6.7 magnitudes is $0.329 \mathrm{~g}$. Its embankment is $5.3 \mathrm{~km}$ far away from the main segment of the North Anatolian Fault Zone given in the updated seismo-tectonic map of Turkey. According to PSHA, the values of peak ground acceleration for OBE and MDE are $0.433 \mathrm{~g}$ and $0.560 \mathrm{~g}$, respectively. The Kocaeli Municipality operates it. This 21-year old rockfill embankment is in excellent condition, but it cannot meet current seismic design standards. It will be under nearfield motion during a forthcoming earthquake. Its TRF value is 146.1, and it has a risk class of III with high risk ratio. Its risk increases because of being no alternative water resources in the region.

Sazlıdere dam is a rockfill dam on the Sazlıdere River near Arnavutköy County. It has a 23.0 m height from river bed. When the reservoir is at maximum capacity, the facility impounds $131.50 \mathrm{hm} 3$ of water with a reservoir surface area of $11.77 \mathrm{~km} 2$. The dam, finished in 1996, has a function to provide domestic water for the İstanbul city with an annual capacity of $55.0 \mathrm{hm} 3$. The crest length is $435 \mathrm{~m}$, and the side slopes of the main embankment are $2.25 \mathrm{H}: 1 \mathrm{~V}$ for upstream and $2.0 \mathrm{H}: 1 \mathrm{~V}$ for downstream $(\mathrm{H}=$ horizontal and $\mathrm{V}=$ vertical). In the section, there are a central impervious core, which is composed of compacted impervious clay, and a transition section of sandy and gravelly aggregates between the core and finely crushed rockfill. According to the DSHA of this study, the peak ground acceleration produced by an earthquake of 7.5 magnitudes is 0.205 $\mathrm{g}$, and its embankment is $23.0 \mathrm{~km}$ far away from an active fault given in the updated seismo-tectonic map of Turkey. The PSHA indicates that the values of peak ground acceleration for OBE and MDE are $0.225 \mathrm{~g}$ and $0.306 \mathrm{~g}$, respectively. Its TRF value is 158.4 , and it has a risk class of III. This 24-year old rockfill embankment is in excellent condition. Its reservoir is under the influence of the Istanbul Canal Project to be realized in forthcoming years.

The Tasoluk dam, constructed as rockfill type with embankment volume of $1.7 \mathrm{hm} 3$ on the Tasoluk River of the Marmara Basin in Canakkale province, has a $65-\mathrm{m}$ height from the river basin. The facility impounds $79.4 \mathrm{hm} 3$ of water when the reservoir is at maximum capacity. The dam, finished in 2009 , has a function to provide irrigation water. The side slopes of main embankment are 2.0H:1V for upstream and downstream $(\mathrm{H}=$ horizontal and $\mathrm{V}=$ vertical). In the section, there is a central impervious core, which is composed of compacted clay, and a transition section of granular material between the core and fine crush rock zone materials for both sides (Fig. 3). According to the seismic hazard analyses of this study, Tasolukdam is one of the most critical structures of Marmara basin that the peak ground acceleration by an earthquake of 5.6 magnitude using the DSHA is $0.261 \mathrm{~g}$. The PSHA indicates that the values of peak ground acceleration for OBE and MDE are $0.460 \mathrm{~g}$ and $0.582 \mathrm{~g}$, respectively. Its TRF value is 116.9, and it has a risk class of III. Dam site is $1.8 \mathrm{~km}$ far away from an active fault. 


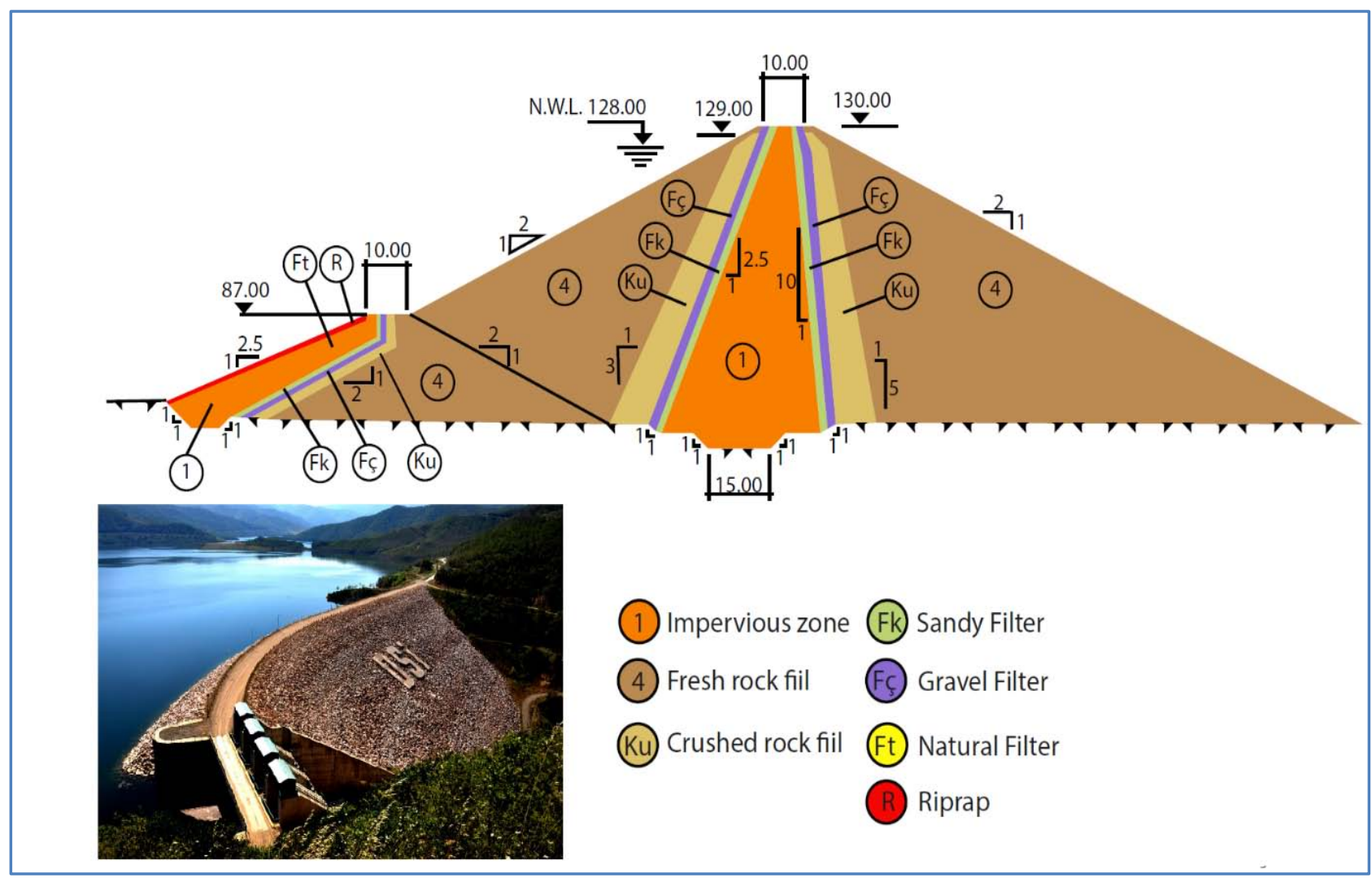

Figure 3: Geometry of Tasoluk dam

The Yenice-Gonen dam is a zoned earth-rockfill dam on the Gonen River near Yenice County, located in the southern portion of the basin. It has a 78-m height from the foundation. It has a reservoir volume of 227 $\mathrm{hm} 3$ with a surface area of $15.4 \mathrm{~km} 2$. Its crest length is $293 \mathrm{~m}$. Its embankment construction was started in 1993 and completed in 1997. It was designed a multipurpose structure for irrigating lands, producing electricity, supplying domestic water, and providing flood control. It is an earth-rockfill dam with a central core. The slopes are $3.0 \mathrm{H}: 1 \mathrm{~V}$ for both sides $(\mathrm{H}=$ horizontal and $\mathrm{V}=$ vertical). The shell is composed of earth and rockfill materials for upstream and downstream, respectively. There is a transition section of sand, gravel, and small-sized crushed rock between the core and shell materials (Fig. 4). The alluvium on the river bed, which is composed of sand, gravel and fine mixtures, was removed before beginning the construction of the main embankment of the dam. The dam axis is very close to the Yenice-Gonen Fault Zone (YGFZ), which extends from Gonen East in the Northeast to Yenice's Southwest in the southwest. This fault zone caused an earthquake on March 18, 1953, with a magnitude of 7.2 . It is only $1.71 \mathrm{~km}$ far away from the surface collapse of YGFZ. The seismic hazard analyses indicate that it is one of the critical dams within the basin. The peak ground acceleration produced by an earthquake of 6.6 magnitudes is $0.394 \mathrm{~g}$. It is only $1.77 \mathrm{~km}$ far away from the active fault. Moreover, its risk is high for downstream life (total risk factor is 214.1 with high-risk ratio). 


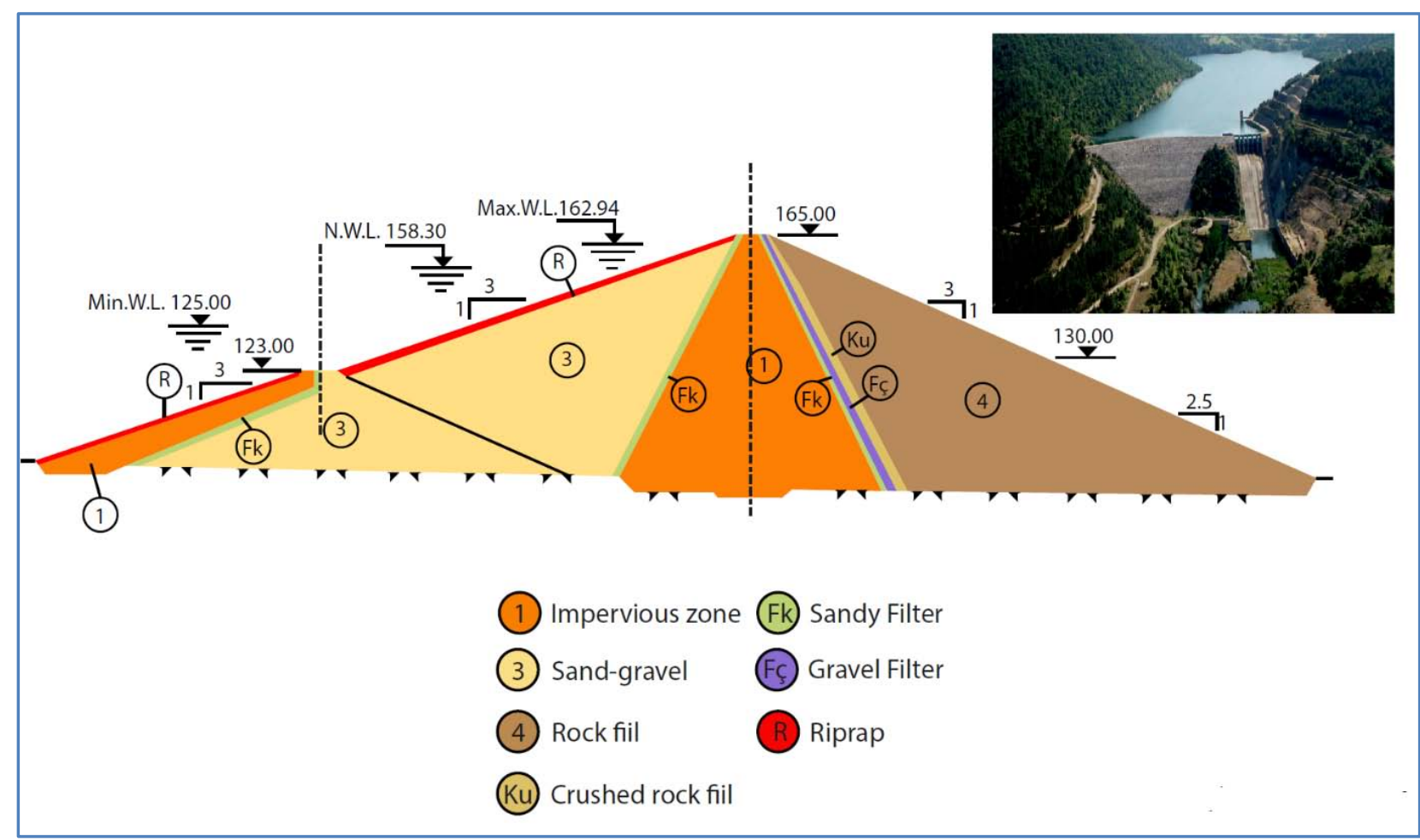

Figure 4: Maximum cross-section of Yenice-Gonen dam

\section{Conclusions}

For this study, nineteen large dams, located on different seismic zones of the Marmara basin, were analyzed to estimate their seismic hazards and risk classes based on the actual earthquakes occurred within the basin and structural features of dams. The North Anatolian Fault zones and its secondary segments are the most critical zone for the basin. There are five existing dams under the near-field motion when considered the new seismo-tectonic map of Turkey. The analyses indicate that Cokal, Gokce, Kirazdere, Tasoluk, and Yenice-Gonen dams are the most critical dams of the basin. Additionally, four large dams (Alibey, BuyukCekmece, Elmali-II, and Sazlidere), possessing the hazard class of III with high hazard ratio, are also critical dams in the Marmara basin. As a result of this study, 47.4 percent of the dams have been identified as the structures in high and extremely high hazard ratios. In comparison, 31.5 percent of dams is in a moderate hazard ratio. The rest are relatively safe structures when we consider public safety. The author points out that local predictive relationships are an appropriate methodology for estimating the seismic parameters to be used in dynamic analyses. The study clarifies another fact that probabilistic seismic hazard analysis introduces relatively higher PGA values for the dams having high earthquake intensity. Development of attenuation relationships between PGA values obtained from probabilistic and deterministic seismic hazard analyses as considering earthquake intensity can be an promising area for forthcoming studies.

\section{References Références Referencias}

1. Ambraseys, NN.1995. The Prediction of Earthquake Peak Ground Acceleration in Europe. Earthquake Engineering and Structural Dynamics, V.24, 467-490.

2. Ambraseys, NN., Douglas, J, Karma, SK and Smit, PM. 2005. Equations for the Estimation of Strong Ground Motions from Shallow Crustal Earthquakes Using Data from Europe and the Middle East. Horizontal Peak Ground Acceleration and Spectral Acceleration, Bulletin of Earthquake Engineering, 3, 1-53.

3. Boore, DM, Joyner, WB. and Fumal, TE. 1993. Estimation of response spectra and peak accelerations from Western North American earthquakes. An interim report. Open file report 93509.U.S.G.S

4. Boore, DM., Joyner, WB. and Fumal, TE. 1997. Equation for Estimating Horizontal Response Spectra and Peak Acceleration from Western North American Earthquakes. A Summary of recent Work. Seismological Research Letters, V.68, N.1, January /February, 128-153.

5. Bureau, GJ. 2003. Dams and Appurtenant Facilities in Earthquake Engineering Handbook edited by Chenh, W.F and Scawthorn,C. CRS press, Bora Raton 26.1-26.47.

6. Campbell, KW. 1981. Near-Source Attenuation of Peak Horizontal Acceleration: Bulletin Seism. Soc. Am., V.71, N.6, 2039-2070. 
7. Campbell, KW. and Bozorgnia, Y. 1994. Nearsource attenuation of peak horizontal acceleration from worldwide accelerograms recorded from 1957 to 1993: Proceeding of the Fifth U.S. National Conference on Earthquake Engineering. V.3, 283-292.

8. DSI. 2012. Selection of Seismic Parameters for Dam Design. State Hydraulic Works, Ankara, 29 p (in Turkish).

9. DSI .2016. Dams of Turkey. TR-COLD, Ankara, $602 \mathrm{p}$.

10. FEMA. 2005. Federal Guidelines for Dam SafetyEarthquake Analyses and Design of Dams.

11. Fraser, WA and Howard, JK. 2002. Guidelines for Use of the Consequence-Hazard matrix and Selection of Ground Motion Parameters: Technical Publication, Department of Water Resources, Division of Safety of Dams.

12. Gulkan, P and Kalkan, E. 2002. Attenuation modeling of recent earthquakes in Turkey. Journal of Seismology, 6(3), 397-409.

13. Hariri-Ardebili, Mohammad A. Salamon, Jerzy; Mazza, Guido; Tosun, Hasan; Xu, Bin. 2020. Advances in Dam Engineering. Infrastructures 5, no. 5: 39.

14. ICOLD. 1989. Selecting Parameters for Large Dams-Guidelines and Recommendations. ICOLD Committee on Seismic Aspects of Large Dams, Bulletin 72.

15. ICOLD. 2016. Selecting Seismic Parameters for Large Dams-Guidelines. ICOLD, Bulletin 148.

16. Jiminez, MJ, Giardini, D and Grünthal, G. 2001. Unified Seismic Hazard Modelling throughout the Mediterranean Region. Bolettino di Geofisica Teoricaed Applicata, Vol.42, N.1-2, Mar-Jun., 3-18.

17. Kalkan, E veGulkan, P. 2004. Site-Dependent Spectra Derived from Ground Motion Records in Turkey, Earthquake Spectra, 20, 4, 1111-1138.

18. Kramer, SL. 1996. Geotechnical Earthquake Engineering: Prentice-Hall, Upper Saddle River, NJ $653 \mathrm{p}$.

19. Krinitzsky, E. 2005. Discussion on Problems in the Application of the SSHAC Probability Method for Assessing Earthquake Hazards at Swiss nuclear power plants. Eng. Geol. 78 285-307; Eng.Geo. 82, 62-68.

20. MTA. 2013. Scale 1/1.125.000 Turkey Live Fault Map. General Directorate of Mineral Research and Exploration. Special publications series, Ankara, Turkey.

21. Seyrek,E. and Tosun, H. 2011. Deterministic approach to the seismic hazard of dam sites in Kızılırmak basin, Turkey. Natural hazards, 59 (2), 787.

22. Seyrek, E and Tosun, H. 2013. Influence of analysis methods for seismic hazard on total risk of large concrete dams in Turkey. GaziUniv, J. Fac Engineering Architecture, 28-1, 67-75.

23. Tosun, H. 2002. Earthquake-Resistant Design for Embankment Dams: Publication of General Directorate of State Hydraulic Works, Ankara. 208 pp. (in Turkish).

24. Tosun, H. and Savas, H. 2005. Seismic hazard analyses of concrete dams in Turkey. in Proceeding of CDA Annual Conference.

25. Tosun, H. 2006. Seismic studies. International Water Power \& Dam Construction, 58 (2), 20-23.

26. Tosun, H. 2007. Total Risk Analysis of Damand Appurtenant Structures in a Basin and a Case Study. International Congress in River Basin Management, Volumel, 22-24 March, Antalya, 477-488.

27. Tosun, H. and Turkoz, M. 2007. Total risk-analyzing methods for dam structures and a case study in Turkey. in Proceeding of CDA Annual Conference.

28. Tosun, H., Zorluer, I. Orhan, A. Seyrek, E. Savaş, H. and Türköz, M. 2007a. Seismic hazard and total risk analyses for large dams in Euphrates basin, Turkey. Engineering Geology 89 (1-2), 155-170,

29. Tosun, H.Türkoz, H. and Savas, H. 2007b. River basin risk analysis. Int. Water Power and Dam Construction, May issue.

30. Tosun, H.Turkoz, M. Savas, H. and Seyrek, E. 2007c. River basin risk analysis. International Water Power and Dam Construction, 59 (5), 30.

31. Tosun, H. 2008. Evaluating Earthquake Safety for Large Dams in Southeast Turkey. Hydro Review Worldwide (HRW), 34-40.

32. Tosun, H. and Seyrek,E. 2010.Total risk analyses for large dams in Kizilirmak basin, Turkey. Natural Hazards and Earth System Sciences, 10 (5), 979.

33. Tosun,H. 2011. Re-analysis of Ataturk Dam under Ground Shaking by Finite Element Models. In Proceeding of CDA Annual Conference, September 22-27. Saskatoon, Canada.

34. Tosun, H. 2012. Earthquake Safety of Keban Dam, Turkey. in Proceeding of CDA Annual Conference, October 15-20. Fredericton, NB, Canada, 2012.

35. Tosun, H. 2015. Earthquakes and dams. in charter of Earthquake Engineering (edited by A. Moustafa), Chapter 7, Intechopen, 189-198. (http://dx.doi.org/ 10.5772/59372).

36. Tosun, $\mathrm{H}$ and Oguz, S. 2017. Stability Analysis of Atatürk dam, Turkey as Based on the Updated Seismic Data and Design Code. in Proceeding of 85th Annual Meeting of International Commission on Large Dams, Prague, 66-66.

37. Tosun, $\mathrm{H}$ and Tosun, V.T. 2017a. Total risk and seismic hazard analyses of large dams in northwest Anatolia, Turkey. ICOLD 85th Annual Meeting, July 3-7, Prague.

38. Tosun, H. and Tosun, V.T. 2017b. Dynamic Analysis of Embankment Dams Under Strong Seismic 
Excitation and a Case Study", in Proceeding of Long-Term Behaviour and Environmentally Friendly Rehabilitation Technologies of Dams (LTBD 2017), Tehran, (DOI:10.3217/978-3-85125-564-5-102)

39. Tosun, H. 2018. Safety Assessment of Large Reservoir Constructed for Domestic Water Near Urban Areas and a Case Study. in Proceeding of ICOLD-ATCOLD Symposium on Hydro Engineering, Wien, 917-927.

40. Tosun, H. and Onder, T.B. 2018. Safety assessment for existing large reservoirs constructed in Istanbul metropolitan area. in Proceeding of 5th International Symposium on Dam Safety. October 27-31. Istanbul.

41. Tosun,H, Tosun,V.T and Hariri-Ardebili, M.A. 2020. Total risk and seismic hazard analysis of large embankment dams: case study of Northwest Anatolia, Turkey. Life Cycle Reliability and Safety Engineering, 1-10, (https://doi.org/10.1007/s41872020-00113-4).

42. Tosun, H. 2019a. Dam Engineering (edited by H.Tosun). Intech Open, (DOI: 10.5772/intechopen. 74153).

43. Tosun, H. 2019b. Earthquake Safety Evaluation for Large Dams in Marmara Basin, Turkey. VI. in Proceeding of International Earthquake Symposium, September 25-27. Kocaeli. Turkey

44. Tosun, H and Seyrek, E. 2012. Selection of the appropriate methodology for earthquake safety assessment of dam structures. In chapter Advances in Geotechnical Earthquake Engineering (edited by A. Moustafa). Intechopen. 167-188 (DOI: 10.5772/29721). 